\title{
Pancreatic solitary and synchronous metastasis from breast cancer: a case report and systematic review of controversies in diagnosis and treatment
}

Carlo Molino ${ }^{1}$, Carmela Mocerino ${ }^{2}$, Antonio Braucci ${ }^{1}$, Ferdinando Riccardi ${ }^{2 *}$, Martino Trunfio ${ }^{1}$, Giovanna Carrillo ${ }^{3}$, Maria Giuseppa Vitale ${ }^{2}$, Giacomo Carteni ${ }^{2}$, Guido De Sena ${ }^{1}$ and On behalf of the Breast Unit Cardarelli Hospital, Naples, Italy

\begin{abstract}
Background: Metastases from breast cancer cause the frequent involvement of lung, bone, liver, and brain, while the occurrence of metastases to the gastrointestinal tract is rare, and more frequently discovered after a primary diagnosis of breast cancer. Solitary pancreatic metastases from breast cancer, without widespread disease, are actually unusual, and only 19 cases have been previously described; truly exceptional is a solitary pancreatic metastasis becoming evident together with the primary breast cancer.

Case presentation: A 68-year-old woman reported general fatigue, lethargy, and jaundice. Abdominal ultrasound (US) and magnetic resonance imaging (MRI) showed an ampulloma of Vater's papilla; moreover, a neoplastic nodule in the left breast was diagnosed. She underwent surgery for both breast cancer and ampulloma of Vater's papilla. Pathological examination of pancreatic specimen, however, did not confirm primary carcinoma of the duodenal papilla, but showed a metastatic involvement of pancreas from lobular breast cancer. Immunohistochemistry has been essential to confirm the origin of the malignancy: hormone receptors and mammaglobin were expressed in both the primary breast tumor and the pancreatic metastasis.

Conclusions: This is one of the few reported cases in literature of an isolated and synchronous pancreatic metastasis from breast cancer, where the definitive diagnosis was obtained only after surgery. We discuss the controversies in this diagnosis and the choice of correct treatment. The surgical resection of solitary metastases can be performed in the absence of disseminated disease.
\end{abstract}

Keywords: Breast cancer, Lobular carcinoma, Pancreatic metastasis, Synchronous metastasis, Mammaglobin

\section{Background}

Breast cancer is the most common malignancy in women [1,2] and metastatic spread causes frequent involvement of lung, bone, liver, and brain [3]. The occurrence of metastases from breast cancer to the gastrointestinal tract and to the pancreas is rare, and more frequently discovered after a primary diagnosis of breast cancer [4,5]. Metastatic spread to the pancreas from different primary is unusual and accounts for appro-

\footnotetext{
* Correspondence: nando.riccardi@alice.it

${ }^{2}$ Department of Oncology, Cardarelli Hospital, Naples, Italy

Full list of author information is available at the end of the article
}

ximately $2 \%$ of pancreatic malignancies [6,7], while metastatic involvement of pancreas from primary breast cancer is a rare event. In a large autopsy series, the prevalence of pancreatic metastases has been described to be as high as $6 \%$ to $11 \%$ [8-10]. Although many patients with pancreatic metastases have widespread disease, isolated metastases to the pancreas can be found [11]. If the metastatic involvement of pancreas from breast cancer is unusual, detection of isolated and synchronous pancreatic metastasis is a really exceptional event, and when an isolated metastasis in the pancreas becomes symptomatic, it is often misdiagnosed as 
primary pancreatic adenocarcinoma. In spite of the development of imaging modalities, the preoperative diagnosis of pancreatic malignancy is still suboptimal. Image-guided fine-needle aspiration (FNA) is an accurate and safe method for evaluating pancreatic lesions, without open biopsy or laparotomy. Here we present one of the few reported cases of synchronous and solitary metastasis to the head of the pancreas from lobular breast cancer, with the purpose to review the clinical presentation, the diagnostic procedures, and therapeutic management.

\section{Case presentation}

In May 2012 a 68-year-old woman complaining of general fatigue, lethargy, and jaundice presented to the Emergency Unit of Cardarelli Hospital. Biochemical tests revealed hyperglycemia $(483 \mathrm{mg} / \mathrm{dl})$, elevated total bilirubin (4.22 mg/dl, with conjugated bilirubin of $3.49 \mathrm{mg} / \mathrm{dl})$, high levels of CA 15.3 (320.6 UI/mL), and CA 19.9 (490.7 UI/mL), while levels of CEA and CA125 were within normal limits. Abdominal ultrasonography (US) showed biliary sludge and bile duct dilation, and magnetic resonance imaging (MRI) with cholangiography confirmed an enlargement of extra-hepatic bile ducts (14 $\mathrm{mm}$ in diameter) evident until the upper papillary tract, where a stop of the signal suggested a tumor of the duodenal papilla (Figure 1). Blurring of the uncinate process of the pancreas and several lymph adenopathies were reported. In a few days the jaundice increased and biochemical tests underlined a liver dysfunction (GOT $200 \mathrm{UI} / \mathrm{L}, \mathrm{GPT} 238 \mathrm{UI} / \mathrm{L}$, ALP $320 \mathrm{UI} / \mathrm{L}, \mathrm{GGT}$ 1,441 UI/L, and cholinesterase 2,540 UI/L). Moreover,

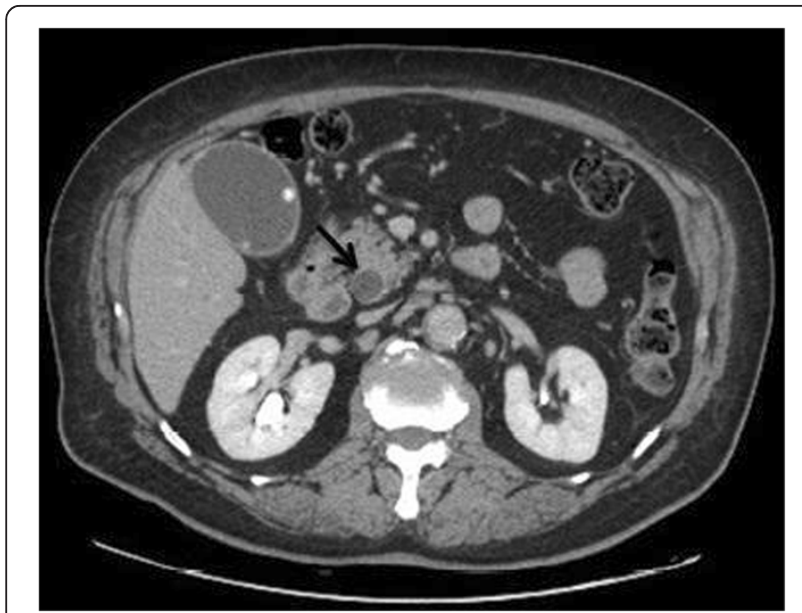

Figure $1 \mathrm{CT}$ scan at the diagnosis. Contrast CTscan of the abdomen demonstrating an enlargement of the common bile duct (14 $\mathrm{mm}$ in diameter, see black arrow) and of the of the gallbladder with an inhomogeneous material into the lumen compatible with biliary sludge and microlithiasis. The extra-hepatic bile ducts swelling was evident until the upper papillary tract. during the diagnostic procedures, a mammary US revealed a hypoechoic nodule of $25 \mathrm{~mm}$ of the left breast with fringed margins. After mammography with FNAC describing a $30 \mathrm{~mm}$ breast carcinoma in the left breast (Figure 2), she was admitted at our department of General Surgery and Breast Unit, with a diagnosis of primary breast cancer and primary carcinoma of the duodenal papilla. Total body CTscan confirmed the previous findings and didnot show other secondary involvements. An ERCP showed an ulcerate papilla, assuming the lesion as an ampulloma, but biopsies were not significant for diagnosis.

In June the patient underwent one-time surgery for both breast cancer and ampulloma of Vater's papilla. During the pancreatic time the gland showed features of infiltrations and intraoperative Trucut biopsies were performed; the confirmation of the presence of poorly differentiated carcinoma suggestive for pancreatic origin allowed us to perform Whipple's procedure. The breast time consisted of Patey's mastectomy for an invasive lobular carcinoma localized in the upper inner left quadrant, measuring $3.2 \mathrm{~cm}$ at its longest dimension. None of the 14 axillaries lymph nodes removed were malignant.

Pathological examination of the pancreatic mass revealed a lesion of $2.5 \mathrm{~cm}$ infiltrating the ampulla and the perivisceral adipose tissue, but surprisingly did not confirm primary adenocarcinoma of the pancreas: microscopic features consisted of a metastatic lobular carcinoma of the breast (Figure 3). Surgical margins of the pancreatic resection were free from neoplastic infiltration as were the isolated lymph nodes.

Breast specimen confirmed a grade II invasive lobular carcinoma (Figure 4) exhibiting high levels of estrogen (90\%) and progesterone receptors (80\%), HER2-negative, ki- $67=20 \%$. Because of the rarity of metastases to the pancreas from breast cancer, a specific immunohystochemical panel was performed to confirm the origin. Mammoglobin was positive, hormone receptors were highly expressed, both in the breast and the pancreatic tumors, confirming secondary pancreatic involvement from lobular carcinoma.

The breast tumor board planned a first-line hormonal therapy for advanced disease with Letrozol, on an outpatient basis. Cytotoxic chemotherapy was not prescribed, while radiotherapy was not indicated. Twelve months after the operation, the patient is alive without evidence of distant metastasis confirmed by total body computed tomography (CT) scan.

\section{Discussion}

\section{Clinical presentation}

The metastatic involvement of the pancreas is most often related to other intra-abdominal malignancies [7], 


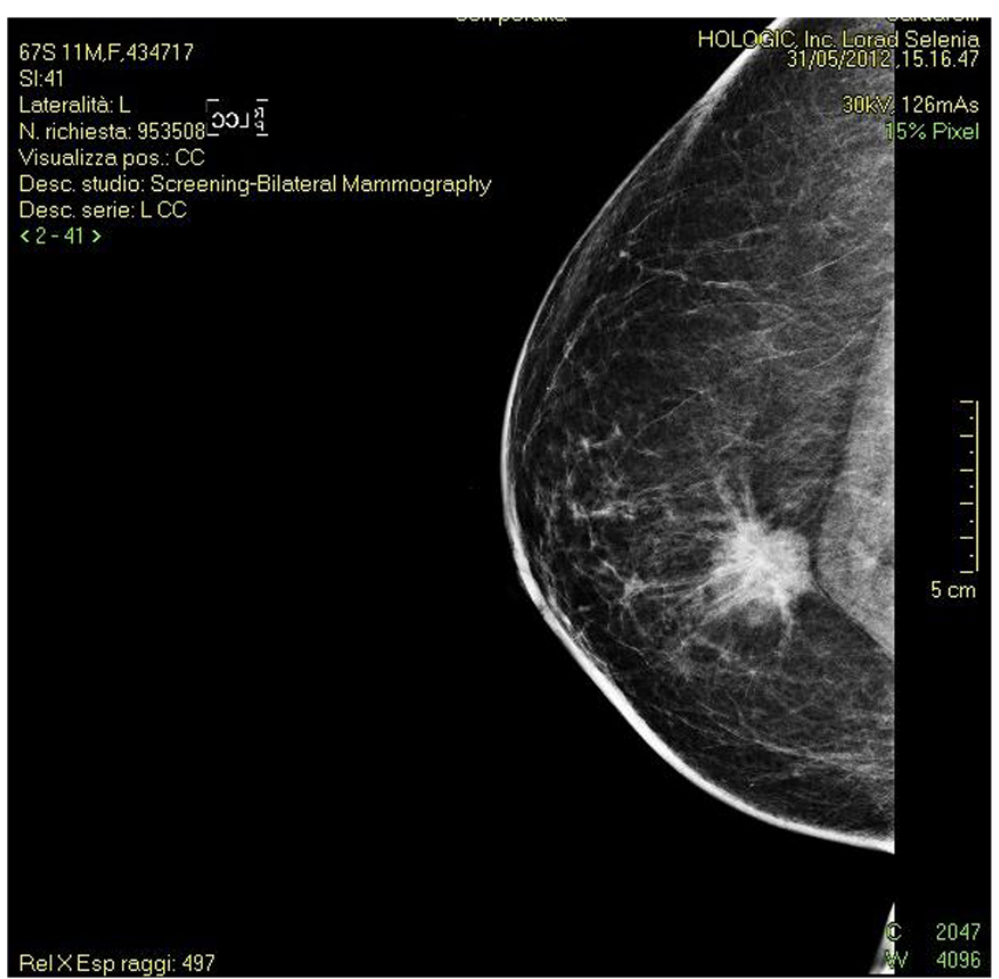

Figure 2 Left mammogram. A nodule with irregular margins revealed in the left breast.

including clear cell kidney cancer, colon cancer, and gastric cancer [12,13]. A report of 1,000 autopsied cases has revealed that for breast cancer the metastatic pancreatic involvement is a rare occurrence ranking at approximately $6 \%$ to $11 \%$ of all malignancies $[5,14]$. Metastatic involvement of the pancreas from primary breast cancer as solitary metastasis sites has an incidence lower than $3 \%$ : the literature reflects the rarity of this clinical scenario with 23 published reports of solitary pancreatic metastases originating from breast cancer (Table 1).

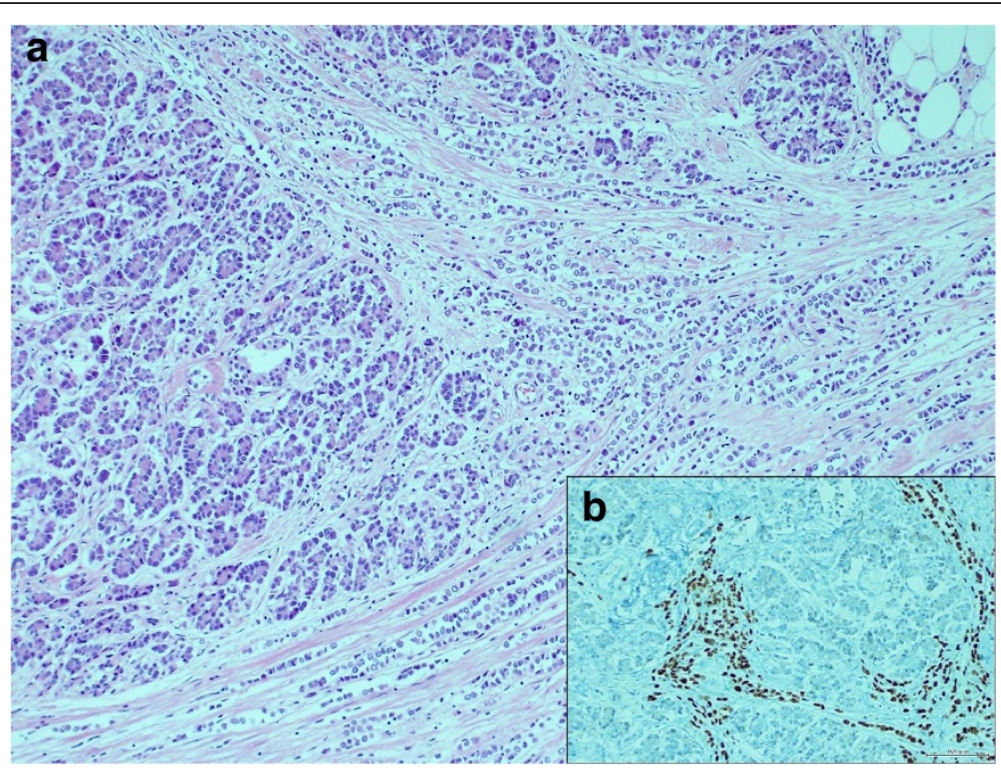

Figure 3 Histological features of pancreatic mass. (a) Small disaggregated tumor cells infiltrating the pancreatic parenchyma (H\&E staining, $\times 100)$. (b) Immunohistochemical staining of ER in the pancreatic head mass $(\times 250)$. 


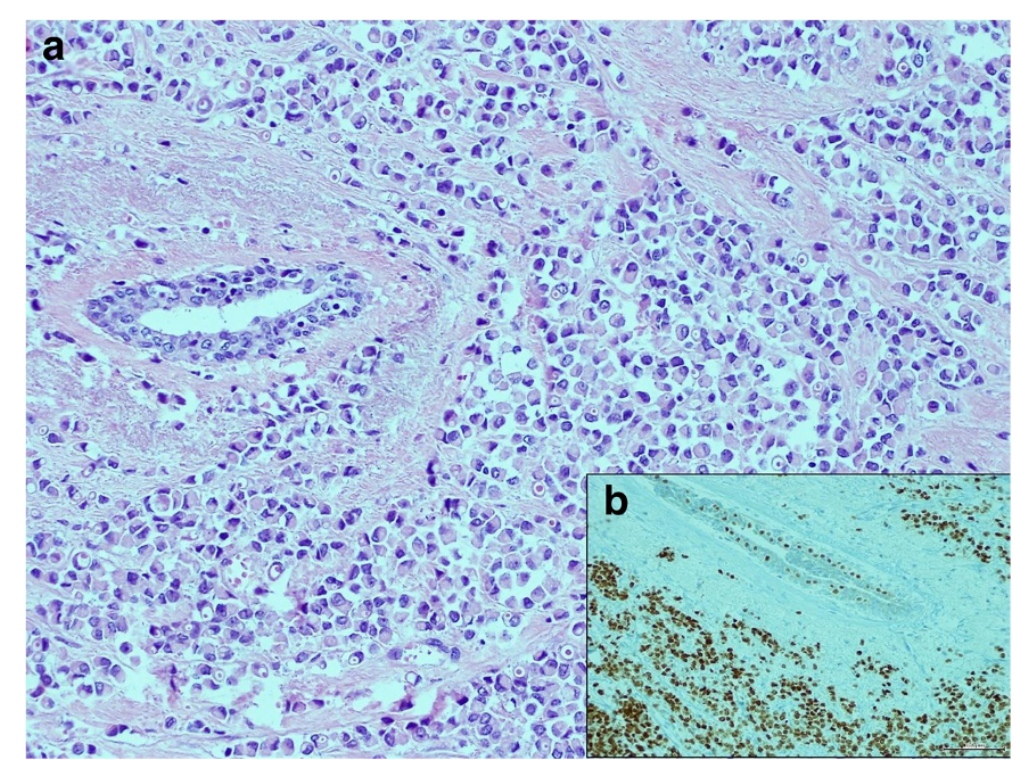

Figure 4 Histological features of breast carcinoma. (a) Breast lobular carcinoma (H\&E staining, $\times 250$ ). (b) Immunohistochemical staining of ER in the breast lobular carcinoma $(\times 250)$.

Metastases may be single or multiple, synchronous or metachronous, sometimes occurring very late. Literature describes an interval time from the first diagnosis and recurrence varies from a few months to several years and considers the synchronous presentation as an extremely rare finding [33]. Cancer metastatic to the pancreas usually develops late in the course of the disease and is associated usually with widespread metastases $[34,35]$. Although pancreatic metastases may clinically mimic primary pancreatic adenocarcinoma [36,37], most patients (50\% to $83 \%)$ with pancreatic metastases are completely asymptomatic and the pancreatic mass is detected on routine follow-up examination [38,39]. Therefore, the presenting symptoms of these specific metastases are not necessarily distinguishable from other types of pancreatic cancer, but the diagnosis should be considered in any patient with a pancreatic mass and a history of breast cancer [40].

\section{Diagnosis}

The lack of clinical symptoms requires the use of the imaging. Most pancreatic metastases are discovered on a CT examination performed during the follow-up of patients with history of primary malignancy [41]. The introduction of contrast-enhanced ultrasonography (CEUS) has improved the diagnostic capabilities of US [42]. In the last decade new diagnostic possibilities for tumors of the pancreas derive from the FDG-PET/CT [43]. Although its role in the diagnostic management of metastases to the pancreas is not well-defined, PET appears particularly useful to exclude other metastatic sites.
However, the FDG-PET/CT is not able in the evaluation of the surgical resectability of malignant lesions.

In most cases the diagnosis of secondary pancreatic tumors along with the differential diagnosis of primary pancreatic adenocarcinomas can still be difficult. Many studies suggest the possibility of a fine-needle biopsy to establish the pathological diagnosis, although some physicians believe that this procedure should be avoided in cases of resettable pancreatic masses. The use of immunocytochemistry, when available, may be useful to confirm a suspected diagnosis [44-46].

In selected patients with pancreatic metastases, surgical resection can be considered the standard of care and may largely ameliorate the survival of the patients. Data from the literature indicate that an improved survival can be achieved in patients with renal, breast, and colon carcinomas and sarcomas as primary malignancy, while patients with melanoma and lung cancer are related with a poor outcome and should be treated non-operatively [47-49]. Even in patients not amenable to surgery, a definitive tissue diagnosis can be helpful in evaluating the possibility and type of chemotherapy. In these cases and in controversial diagnostic cases, CT can be considered as an important tool in providing guidance in order to obtain a definitive tissue diagnosis [50-52].

Immunohistochemistry (IHC) has a key role in the diagnosis of mammary disease and also to discriminate metastatic breast cancer from primary pancreatic carcinoma [53-56]. Differences in Cytokeratin (CK) profile and molecular weight may aid to distinguish ductal from lobular carcinomas [57-60], in primary as in metastatic sites. 
Table 1 Clinical features of the patients with pancreatic metastases from primary breast cancer

\begin{tabular}{|c|c|c|c|c|c|c|c|c|c|}
\hline $\begin{array}{l}\text { Author and } \\
\text { reference }\end{array}$ & $\begin{array}{l}\text { Patients with } \\
\text { pancreatic } \\
\text { metastases }(n)\end{array}$ & $\begin{array}{l}\text { Patients with primary } \\
\text { breast cancer }(n) \text { and } \\
\text { subtype }\end{array}$ & $\begin{array}{l}\text { Age } \\
\text { (years) }\end{array}$ & $\begin{array}{l}\text { Disease-free } \\
\text { interval } \\
\text { (months) }\end{array}$ & $\begin{array}{l}\text { Presenting } \\
\text { symptoms }\end{array}$ & $\begin{array}{l}\text { Localization of } \\
\text { metastases at } \\
\text { diagnosis }\end{array}$ & $\begin{array}{l}\text { Characteristics of } \\
\text { metastasis at } \\
\text { diagnosis }\end{array}$ & Clinical management & $\begin{array}{l}\text { Outcome } \\
\text { (overall survival } \\
\text { in months) }\end{array}$ \\
\hline Akashi [15] & 15 & 1 (lobular) & 47 & 41 & NR & Head of pancreas & Solitary & Pancreaticoduodenectomy & 28 \\
\hline Bonapasta [16] & 1 & 1 (ductal) & 51 & 24 & $\begin{array}{l}\text { Jaundice, } \\
\text { pain }\end{array}$ & Head of pancreas & Solitary & $\begin{array}{l}\text { Cephalic } \\
\text { pancreaticoduodenectomy }\end{array}$ & 36 \\
\hline Azzarelli [17] & 1 & 1 (lobular) & 49 & 43 & Jaundice & Head of pancreas & Solitary & Pancreaticoduodenectomy, RT & 72 \\
\hline \multirow[t]{2}{*}{ Bednar [18] } & 2 & 1 (lobular) & 75 & 96 & $\begin{array}{l}\text { Jaundice, } \\
\text { pain }\end{array}$ & Head of pancreas & Solitary & Pancreaticoduodenectomy & 48 \\
\hline & & 1 (phyllodes) & 57 & 48 & $\begin{array}{l}\text { Abdominal } \\
\text { pain }\end{array}$ & $\begin{array}{l}\text { Head of pancreas, } \\
\text { lung }\end{array}$ & $\begin{array}{l}\text { Widespread } \\
\text { disease }\end{array}$ & $\mathrm{CHT}$ & 15 \\
\hline \multirow[t]{3}{*}{ Crippa [19] } & 13 & 1 (lobular) & 46 & 60 & Jaundice & Head of pancreas & Solitary & $\begin{array}{l}\text { Pylorus preserving } \\
\text { pancreaticoduodenectomy }\end{array}$ & 22 \\
\hline & & 1 (lobular) & 70 & 36 & $\begin{array}{l}\text { Jaundice, } \\
\text { pain }\end{array}$ & Head of pancreas & Solitary & $\begin{array}{l}\text { Pylorus preserving } \\
\text { pancreaticoduodenectomy }\end{array}$ & 38 \\
\hline & & 1 (lobular) & 57 & 84 & $\begin{array}{l}\text { Jaundice, } \\
\text { pain }\end{array}$ & Head of pancreas & Solitary & $\begin{array}{l}\text { Pylorus preserving } \\
\text { pancreaticoduodenectomy }\end{array}$ & 26 \\
\hline Dar [20] & 5 & 1 (ductal) & 76 & 108 & NR & Pancreas, liver & $\begin{array}{l}\text { Widespread } \\
\text { disease }\end{array}$ & Palliative bypass & 6 \\
\hline Engel [21] & 1 & 1 (signet-ring cells) & 59 & 46 & $\begin{array}{l}\text { Pruritis, dark } \\
\text { urine }\end{array}$ & Head of pancreas & Solitary & By-pass, CHT & 15 \\
\hline Kitamura [22] & 1 & 1 (ductal) & 55 & 117 & Jaundice & Head of pancreas & Solitary & $\begin{array}{l}\text { Percutaneous } \\
\text { transhepaticcholangio-drainage }\end{array}$ & 1 \\
\hline Le Borgne [23] & 12 & 1 (lobular) & 48 & Synchronous & Jaundice & Head of pancreas & Solitary & Pancreaticoduodenectomy, CHT & 12 \\
\hline Mehta [24] & 1 & 1 (comedo type) & 30 & 36 & $\begin{array}{l}\text { Jaundice, } \\
\text { pruritis }\end{array}$ & Head of pancreas & Solitary & $\begin{array}{l}\text { Pancreaticoduodenectomy, CHT, } \\
\text { HT }\end{array}$ & 27 \\
\hline Mountney [25] & 1 & 1 (lobular) & 57 & 16 & Jaundice & Head of pancreas & Solitary & By-pass, HT & 24 \\
\hline \multirow[t]{2}{*}{ Moussa [26] } & 22 & 1 (ductal) & 53 & 132 & $\begin{array}{l}\text { Acute } \\
\text { pancreatitis }\end{array}$ & Head of pancreas & Solitary & $\mathrm{RT}, \mathrm{CHT}, \mathrm{HT}$ & 50 \\
\hline & & 1 (lobular) & 35 & 45 & $\begin{array}{l}\text { Abdominal } \\
\text { mass }\end{array}$ & Body of pancreas & Solitary & Total pancreatectomy, CHT & 7 \\
\hline Nomizu [27] & 1 & 1 (lobular) & 46 & 80 & Jaundice & Head of pancreas & Solitary & $\begin{array}{l}\text { Pancreaticoduodenectomy, } \\
\mathrm{CHT}, \mathrm{HT}\end{array}$ & 18 \\
\hline Pan [28] & 6 & 1 (lobular) & 59 & 182 & Jaundice & Head of pancreas & Solitary & $\mathrm{CHT}, \mathrm{HT}$ & 21 \\
\hline Pappo [29] & 1 & 1 (lobular) & 52 & 24 & Jaundice & $\begin{array}{l}\text { Pancreas, } \\
\text { gallbladder }\end{array}$ & $\begin{array}{l}\text { Widespread } \\
\text { disease }\end{array}$ & Bypass, HT & 16 \\
\hline
\end{tabular}


Table 1 Clinical features of the patients with pancreatic metastases from primary breast cancer (Continued)

\begin{tabular}{|c|c|c|c|c|c|c|c|c|c|}
\hline \multirow[t]{3}{*}{ Pérez Ochoa [30] } & 2 & 1 (lobular) & 60 & 1 & Jaundice & Head of pancreas, & $\begin{array}{l}\text { Widespread } \\
\text { disease }\end{array}$ & Biliary stent, cephalic & 2 \\
\hline & & & & & & Bone & & Pancreaticoduodenectomy, CHT & \\
\hline & & 1 (ductal) & 55 & 108 & None & Tail of pancreas & Solitary & $\begin{array}{l}\text { Distal pancreatectomy, } \\
\text { splenectomy, CHT }\end{array}$ & 2 \\
\hline Tohnosu [31] & 1 & 1 (scirrhous type) & 54 & 52 & None & Tail of pancreas & Solitary & Distal pancreatectomy, CHT, HT & 5 \\
\hline Z'graggen [32] & 10 & 1 (lobular) & NR & 96 & Jaundice & Head of pancreas & Solitary & $\begin{array}{l}\text { Biliary and gastric bypass } \\
\text { (hepaticojejunostomy and } \\
\text { gastrojejunostomy), CHT }\end{array}$ & 54 \\
\hline
\end{tabular}


Approximately $75 \%$ to $80 \%$ of human breast tumors express hormone receptors (HRs), the estrogen receptor (ER), and/or the progesterone receptor (PgR). In a large study of 5,993 breast cancers, the positive rate for ER was noted to correlate with nuclear grade of the tumor [61].

Mammaglobin is a recently described marker of breast differentiation [62-64]: its expression has been reported in $70 \%$ to $80 \%$ of primary and metastatic breast tumors and overexpression in breast cancer tissues is associated with an unfavorable prognosis [65]. Moreover, because its expression is not altered at the metastatic site, mammaglobin may aid in the identification of breast carcinomas presenting in metastatic spread [62,66], while changes in ER, PgR, and HER2 status have been described in a significant number of patients over the course of disease progression [67].

\section{Treatment}

The vast majority of metastatic breast cancers are incurable; hence, the primary goals of systemic treatment are prolongation of survival, alleviation of symptoms, and maintenance or improvement in quality of life $[68,69]$.

In HR-positive and HER-2-negative disease, endocrine therapy is the treatment of first choice independent of metastatic site, unless rapid response is needed. Limited visceral metastases are not a contraindication for endocrine therapy. The choice of endocrine agent should be based on menopausal status, co-morbidities, agents received in the adjuvant setting, and the drug safety profile. If the disease progresses rapidly (within a few months) following initiation of first-line endocrine therapy, chemotherapy is generally recommended as a second-line. After chemotherapy response stabilizes (usually 4 to 6 months), a maintenance endocrine therapy can be considered [70].

Surgery can be considered a first choice of treatment not only to differentiate between metastasis and primary pancreatic carcinoma, but also to enable survival given the improved outcome with pancreatic resection in recent decades [71,72]. Resections of pancreatic metastasis account for less than $5 \%$ of all pancreatic resections [73]; in fact, only few patients with isolated disease to the pancreas should be considered for surgical resection.

Several studies [11] have demonstrated that the resection of both pancreatic and limited extrapancreatic mass can be performed with low risk for the patient, as confirmed by our case. Although the role of pancreaticoduodenectomy is not clearly defined in the management of metastatic lesions, it seems to be associated with improved survival and useful palliation. Therefore the resection of an isolated metastasis to the pancreas seems to be an advantageous element for prognosis respect to the resection of a primary tumor of the pancreas, with a 5 -year survival rate of $15 \%$ to $20 \%$ compared to a median survival after successful resection of approximately 12 - to 19 months, respectively [12].

\section{Conclusion}

We described a very rare case of a patient with primary breast cancer and a misdiagnosed synchronous primary carcinoma of the duodenal papilla. After the preoperative diagnosis, our patient was treated with a surgical approach. On the basis of the preoperative findings, we performed a pancreaticoduodenectomy followed by a mastectomy to treat two synchronous primary cancers. Only subsequent pathological examinations of surgical specimens revealed that the finding in the pancreas and duodenum was actually a solitary metastasis by a lobular breast cancer.

The peculiarity of our report is that it is one of the few cases published in the literature of an isolated and synchronous pancreatic metastasis from breast cancer. Usually, the interval time from first diagnosis and recurrence varies from a few months to several years, and synchronous presentation is an extremely rare event. Table 1 shows the clinical features of the patients with pancreatic metastases from different malignancies. Among those, 23 patients exhibited metastatic involvement of the pancreas from primary breast cancer, but in 19 of these patients the metastasis was a solitary secondary lesion, without widespread disease, becoming evident several months after the primary. Only in one case, interestingly, a solitary pancreatic metastasis became evident together with the primary breast cancer, that is to say 'synchronous'; therefore, our case seems to be the second reported in the literature.

The analysis of the current data shows that a radical surgery of both primary malignancy and its metastasis is a possible therapeutic approach for breast carcinoma associated to an isolated pancreatic metastasis, although in most cases clinical presentation of pancreatic lesions occurs only when the primary disease is in advanced stage.

\section{Consent}

Written informed consent was obtained from the patient for publication of this case report and any accompanying images. A copy of the written consent is available for review by the Editor of this journal.

\section{Competing interests}

The authors declare that they have no competing interests.

\section{Authors' contributions}

$F R$, AB, and CMoc drafted the manuscript. MGV, MT, GC, GC, CMol, and GDS helped to review the literature and to draft the manuscript. All authors read and approved the final manuscript.

\section{Authors' information}

FR, MT, and GC are specialists at the Breast Unit of Cardarelli Hospital. GDS is Head of Department of General Surgery and GC is Head of Department of Oncology. MGV is a student of the Postgraduate School of Medical Oncology at the SUN (Second University of Naples), in application to the Cardarelli Hospital. 


\section{Acknowledgements}

We thank Carmela Barbato, Erica Battista (Oncology Dpt.) and Laura Zeuli (Biotechnology Center) for their substantial contribution in the acquisition of the data.

\section{Author details}

'Department of General Surgery and Breast Unit, Cardarelli Hospital, Naples, Italy. ${ }^{2}$ Department of Oncology, Cardarelli Hospital, Naples, Italy. ${ }^{3}$ Department of Pathology, Cardarelli Hospital, Naples, Italy.

Received: 4 August 2013 Accepted: 16 December 2013

Published: 5 January 2014

\section{References}

1. Jemal A, Siegel R, Ward E, Hao Y, Xu J, Thun MJ: Cancer statistics 2009. CA Cancer J Clin 2009, 59:225-249.

2. American Cancer Society: Cancer facts and Figures 2012. New York: American Cancer Society; 2012.

3. Dent R, Hanna WM, Trudeau M, Rawlinson E, Sun P, Narod SA: Pattern of metastatic spread in triple-negative breast-cancer. Breast Cancer Res Treat 2009, 115:423-428.

4. Ghirarduzzi A, Sivelli R, Martella E, Bella M, De Simone B, Arcuri MF, Zannoni M, Del Rio P, Sianesi M: Gastric metastasis from breast carcinoma. Report of three cases, diagnostic-therapeutic critical close examination and literature review. Ann Ital Chir 2010, 81:141-146.

5. Lee YT: Breast carcinoma: pattern of metastasis at autopsy. J Surg Oncol 1983, 23:175-180.

6. Hiotis SP, Klimstra DS, Conlon KC, Brennan MF: Results after pancreatic resection for metastatic lesions. Ann Surg Oncol 2002, 7:675-679.

7. Reddy $\mathrm{S}$, Wolfgang $\mathrm{CL}$ : The role of surgery in the management of isolated metastases to the pancreas. Lancet Oncol 2009, 10:287-293.

8. Alzahrani MA, Schmulewitz N, Grewal S, Lucas FV, Turner KO, McKenzie JT, Sussman JJ, Ahmad SA: Metastases to the pancreas: the experience of a high volume center and a review of the literature. J Surg Oncol 2012, 105:156-161.

9. Sohn TA, Yeo CJ, Cameron JL, Nakeeb A, Lillemoe KD: Renal cell carcinoma metastatic to the pancreas: results of surgical management. J Gastrointest Surg 2001, 5:346-351.

10. Wente MN, Bergmann F, Frohlich BE, Schirmacher P, Buchler MW, Friess $\mathrm{H}$ : Pancreatic metastasis from gastric carcinoma: a case report. World J Surg Oncol 2004, 2:43.

11. Sperti C, Pasquali C, Liessi G, Pinciroli L, Decet G, Pedrazzoli S: Pancreatic resection for metastatic tumors to the pancreas. J Surg Oncol 2003, 83:161-166.

12. Reddy S, Edil BH, Cameron JL, Pawlik TM, Herman JM, Gilson MM, Campbell KA, Schulik RD, Ahuja N, Wolfgang CL: Pancreatic resection of isolated metastases from nonpancreatic primary cancers. Ann Surg Oncol 2008, 15:3199-3206.

13. Sweeny AD, Fisher WE, Wu MF, Hilsenbeck SG, Brunicardi FC: Value of pancreatic resection for cancer metastatic to the pancreas. I Surg Res 2010, 160:268-276

14. Abrams HL, Spiro R, Goldstein N: Metastases in carcinoma: analysis of 1000 autopsied cases. Cancer 1950, 3:74-85.

15. Akashi Y, Saiura A, Kishi Y, Koga R, Morimura R, Yoshioka R, Yamamoto J, Yamaguchi T: Outcome after surgical resection of isolated metastases to the pancreas. Hepato gastroenterology 2010, 57:1549-1552.

16. Bonapasta SA, Gregori M, Lanza R, Sangiorgi E, Menghi A, Scarpini M, Modesti M: Metastasis to the pancreas from breast cancer: difficulties in diagnosis and controversies in treatment. Breast Care 2010, 5:170-173.

17. Azzarelli A, Clemente C, Quagliuolo V, Baticci F: A case of pancreatoduodenectomy as resolutive treatment for a solitary metastasis of breast cancer. Tumori 1982, 68:331-335.

18. Bednar F, Scheiman JM, McKenna BJ, Simeone DM: Breast cancer metastases to the pancreas. J Gastrointest Surg 2013, 17:1826-1831.

19. Crippa S, Angelini C, Mussi C, Bonardi C, Romano F, Sartori P, Uggeri F, Bovo G: Surgical treatment of metastatic tumors to the pancreas: a single center experience and review of the literature. World J Surg 2006, 30:1536-1542

20. Dar FS, Mukherjee S, Bhattacharya S: Surgery for secondary tumors of the pancreas. HPB 2008, 10:498-500.

21. Engel JJ, Trujillo Y, Spellberg M: Metastatic carcinoma of the breast: a cause of obstructive jaundice. Gastroenterology 1980, 78:132-135.
22. Kitamura N, Murata S, Abe H, Hanasawa K, Tsukashita S, Tani T: Obstructive jaundice in a metastatic tumor of the pancreas from breast cancer: a case report. Jpn J Clin Oncol 2003, 33:93-97.

23. Le Borgne J, Partensky C, Glemain P, Dupas B, de Kerviller B: Pancreaticoduodenectomy for metastatic ampullary and pancreatic tumors. Hepatogastroenterology 2000, 47:540-544.

24. Mehta SA, Jagannath P, Krishnamurthy SC, De Souza L: Isolated pancreatic metastasis from locally controlled breast cancer: a case report. Indian J Cancer 1991, 28:48-50.

25. Mountney J, Maury AC, Jackson AM, Coleman RE, Johnson AG: Pancreatic metastases from breast cancer: an unusual cause of biliary obstruction. Eur J Surg Oncol 1997, 23:574-576.

26. Moussa A, Mitry E, Hammel P, Sauvanet A, Nassif T, Palazzo L, Malka D, Delchier JC, Buffet C, Chaussade S, Aparico T, Lasser P, Rougier P, Lesur G: Pancreatic metastases: a multicentric study of 22 patients. Gastroenterol Clin Biol 2004, 28:872-876.

27. Nomizu T, Katagata N, Matsuoka T, Suzuki S, Yabuta T, Watanabe F, Yamaki Y, Saito T, Tsuchiya A, Abe R: A case of breast cancer metastatic to the head of the pancreas. Breast Cancer 1999, 6:131-134.

28. Pan B, Lee $Y$, Rodriguez T, Lee J, Saif MW: Secondary tumors of the pancreas: a case series. Anticancer Res 2012, 32:1449-1452.

29. Pappo I, Feigin E, Uziely B, Amir G: Biliary and pancreatic metastases of breast carcinoma: is surgical palliation indicated? J Surg Oncol 1991, 46:211-214

30. Pérez Ochoa A, Sáez Hernáez F, Cajigas Fernández C, Perez de la Lastra L, Ondiviela Gracia R, Garcia de Polavieja M: Pancreatic metastases from ductal and lobular carcinomas of the breast. Clin Transl Oncol 2007, 9:603-605.

31. Tohnosu N, Narushima K, Sunouchi K, Saito T, Shimizu T, Tanaka H, Maruyama T, Watanabe Y, Kato T, Shimizu S, Uehara T, Ishii S: A case of breast cancer metastatic to the tail of the pancreas. Breast Cancer 2006, 13:225-229.

32. Z'graggen K, Fernández-del Castillo C, Rattner DW, Sigala H, Warshaw AL: Metastases to the pancreas and their surgical extirpation. Arch Surg 1998, 133:413-417.

33. Mylonas I, Janni W, Friese K, Gerber B: Unexpected metastatic lobular carcinoma of the breast with intraabdominal spread and subsequent port site metastasis after diagnostic laparoscopy for exclusion of ovarian cancer. Gynecol Oncol 2004, 95:405-408.

34. Tuech JJ, Pessaux P, Chautard D, Rouge C, Binelli C, Bergamaschi R, Arnaud JP: Results of duodenopancreatectomy for solitary pancreatic metastasis from renal cell carcinoma. J Hepatobiliary Pancreat Surg 1999, 6:396-398.

35. McLemore EC, Pockaj BA, Reynolds C, Gray RJ, Hernandez JL, Grant CS, Donohue JH: Breast cancer: presentation and intervention in women with gastrointestinal metastasis and carcinomatosis. Ann Surg Oncol 2005, 12:886-894

36. Scatarige JC, Horton KM, Sheth S, Fishman EK: Pancreatic parenchymal metastases: observations on helical CT. AJR Am J Roentgenol 2001 176:695-699.

37. Merkle EM, Boaz T, Kolokythas O, Haaga JR, Lewin JS, Brambs HJ: Metastases to the pancreas. Br J Radiol 1998, 71:1208-1214.

38. Muranaka T, Teshima K, Honda H, Nanjo T, Hanada K, Oshiumi Y: Computed tomography and histologic appearance of pancreatic metastases from distant sources. Acta Radiol 1989, 30:615-619.

39. Mullady DK, Slivka A: Acute pancreatitis secondary to metastatic lobular breast carcinoma. Report of a case and review of the literature. Pancreas 2007, 35:194-196.

40. Schwartz RE, Klimstra DS, Turnbull DM: Metastatic breast cancer masquerading as gastrointestinal primary. Am J Gastroenterol 1998, 93:111-114.

41. Boudghène FP, Deslandes PM, LeBlanche AF, Bigot JM: US and CT imaging features of intrapancreatic metastases. J Comput Assist Tomogr 1994, 18:905-910.

42. D'Onofrio M, Zamboni G, Faccioli N, Capelli P, PozziMucelli R: Ultrasonography of the pancreas. 4. Contrast-enhanced imaging. Abdom Imaging 2007, 32:171-181.

43. Kauhanen SP, Komar G, Seppänen MP, Dean Kl, Minn HR, Kajander SA Rinta-Kiikka I, Alanen K, Borra RJ, Puolakkainen PA, Nuutila P, Ovaska JT: A prospective diagnostic accuracy study of $18 \mathrm{~F}$-fluorodeoxyglucose positron emission tomography/computed tomography, multidetector row computed tomography, and magnetic resonance imaging in primary diagnosis and staging of pancreatic cancer. Ann Surg 2009, 250:957-963. 
44. Varytimiadis K, Kalaitzakis E, Salla C, Ghika E, Pandazopoulou A, Karoumpalis I: Pancreatic metastasis of thymic neuroendocrine carcinoma: is there a role for endoscopic ultrasound?: report of a case and review of the literature. Pancreas 2009, 38:230-232.

45. DeWitt J, Jowell P, Leblanc J, McHenry L, McGreevy K, Cramer H, Volmar K, Sherman S, Gress F: EUS-guided FNA of pancreatic metastases: a multicenter experience. Gastrointest Endosc 2005, 61:689-696.

46. Mclntire M, Siziopikou K, Patil J, Gattuso P: Synchronous metastases to the liver and pancreas from a primary neuroendocrine carcinoma of the breast diagnosed by fine-needle aspiration. Diagn Cytopathol 2008, 36:54-57.

47. Zerbi A, Ortolano E, Balzano G, Borri A, Beneduce AA, Di Carlo V: Pancreatic metastasis from renal cell carcinoma: which patients benefit from surgical resection? Ann Surg Oncol 2008, 15:1161-1168.

48. Minni F, Casadei R, Perenze B, Greco VM, Marrano N, Margiotta A, Marrano D: Pancreatic metastases: observations of three cases and review of the literature. Pancreatology 2004, 4:509-520.

49. Yamamoto H, Watanabe $K$, Nagata M, Honda I, Watanabe S, Soda H, Tatezaki S: Surgical treatment for pancreatic metastasis from soft-tissue sarcoma: report of two cases. Am J Clin Oncol 2001, 24:198-200.

50. Ascenti G, Visalli C, Genitori A, Certo A, Pitrone A, Mazziotti S: Multiple hypervascular pancreatic metastases from renal cell carcinoma: dynamic MR and spiral CT in three cases. Clin Imaging 2004, 28:349-352.

51. Fritscher-Ravens A, Sriram PV, Krause C, Atay Z, Jaeckle S, Thonke F, Brand B, Bohnacker S, Soehendra N: Detection of pancreatic metastases by EUS-guided fine-needle aspiration. Gastrointest Endosc 2001, 53:65-70.

52. Klein KA, Stephens DH, Welch TJ: CT characteristics of metastatic disease of the pancreas. Radiographics 1998, 18:369-378.

53. Moll R, Mitze M, Frixen UH, Birchmeier W: Differential loss of E-cadherin expression in infiltrating ductal and lobular breast carcinomas. Am J Pathol 1993, 143:1731-1742

54. Goldstein NS, Bassi D, Watts JC, Layfield LJ, Yaziji H, Gown AM: E-cadherin reactivity of 95 noninvasive ductal and lobular lesions of the breast. Implications for the interpretation of problematic lesions. Am J Clin Pathol 2001, 115:534-542.

55. Acs G, Lawton TJ, Rebbeck TR, LiVolsi VA, Zhang PJ: Differential expression of E-cadherin in lobular and ductal neoplasms of the breast and its biologic and diagnostic implications. Am J Clin Pathol 2001, 115:85-98.

56. Palacios J, Sarrió D, García-Macias MC, Bryant B, Sobel ME, Merino MJ: Frequent $\mathrm{E}$-cadherin gene inactivation by loss of heterozygosity in pleomorphic lobular carcinoma of the breast. Mod Pathol 2003, 16:674-678.

57. Bratthauer GL, Miettinen M, Tavassoli FA: Cytokeratin immunoreactivity in lobular intraepithelial neoplasia. J Histochem Cytochem 2003, 51:1527-1531.

58. Bratthauer GL, Moinfar F, Stamatakos MD, Mezzetti TP, Shekitka KM, Man YG, Tavassoli FA: Combined E-cadherin and high molecular weight cytokeratin immunoprofile differentiates lobular, ductal, and hybrid mammary intraepithelial neoplasias. Hum Pathol 2002, 33:620-627.

59. Lacroix-Triki M, Mery E, Voigt JJ, Istier L, Rochaix P: Value of cytokeratin 5/6 immunostaining using D5/16 B4 antibody in the spectrum of proliferative intraepithelial lesions of the breast. A comparative study with 34betaE12 antibody. Virchows Arch 2003, 442:548-554.

60. Lehr HA, Folpe A, Yaziji H, Kommoss F, Gown AM: Cytokeratin 8 immunostaining pattern and E-cadherin expression distinguish lobular from ductal breast carcinoma. Am J Clin Pathol 2000, 114:190-196.

61. Nadji M, Gomez-Fernandez C, Ganjei-Azar P, Morales AR: Immunohistochemistry of estrogen and progesterone receptors reconsidered: experiences with 5,993 breast cancers. Am J Clin Pathol 2005, 123:21-27.

62. Waston MA, Fleming TP: Mammaglobin, a mammary-specific member of the uteroglobin gene family, is overexpressed in human breast cancer. Cancer Res 1996, 56:860-865.

63. Miele L, Cordella-Miele E, Mantile G, Peri A, Mukherjee AB: Uteroglobin and uteroglobin-like proteins: the uteroglobin family of proteins. J Endocrinol Invest 1994, 17:679-692.

64. Grünewald K, Haun M, Fiegl M, Urbanek M, Muller-Holzner E, Massoner A, Riha K, Propst A, Marth C, Gastl G: Mammaglobin expression in gynecologic malignancies and malignant effusions detected by nested reverse transcriptase-polymerase chain reaction. Lab Invest 2002, 82:1147-1153.

65. Min CJ, Tafra L, Verbanac KM: Identification of superior markers for polymerase chain reaction detection of breast cancer metastases in sentinel lymph nodes. Cancer Res 1998, 58:4581-4584.
66. Waston MA, Fleming TP: Isolation of differentially expressed sequence tags from human breast cancer. Cancer Res 1994, 54:4598-4602.

67. Amir E, Clemons M, Purdie CA, Miller N, Quinlan P, Geddie W, Coleman RE, Freedman OC, Jordan LB, Thompson AM: Tissue confirmation of disease recurrence in breast cancer patients: pooled analysis of multi-centre, multi-disciplinary prospective studies. Cancer Treat Rev 2012, 38:708-714.

68. Stockler M, Wilcken NR, Ghersi D, Simes RJ: Systematic reviews of chemotherapy and endocrine therapy in metastatic breast cancer. Cancer Treat Rev 2000, 26:151-168.

69. Osoba D: Health-related quality of life as a treatment endpoint in metastatic breast cancer. Can J Oncol 1995, Suppl 1:47-53.

70. Geels P, Eisenhauer E, Bezjak A, Zee B, Day A: Palliative effect of chemotherapy: objective tumor response is associated with symptom improvement in patients with metastatic breast cancer. J Clin Oncol 2000, 18:2395-2405

71. Medina-Franco $H$, Halpern NB, Aldrete JS: Pancreaticoduodenectomy for metastatic tumors to the periampullary region. J Gastrointest Surg 1999, 3:119-122.

72. Niedergethmann M, Richter A, Wendl K, Schmidt B, Post S, Trede M: Rare indications for Kaush-Whipple procedure. Eur J Surg 2001, 167:115-119.

73. Konstantinidis IT, Dursun A, Zheng H, Wargo JA, Thayer SP, Fernandez-del Castillo C, Warshaw AL, Ferrone CR: Metastatic tumors in the pancreas in the Modern Era. J Am Coll Surg 2010, 211:749-753.

doi:10.1186/1477-7819-12-2

Cite this article as: Molino et al:: Pancreatic solitary and synchronous metastasis from breast cancer: a case report and systematic review of controversies in diagnosis and treatment. World Journal of Surgical Oncology 2014 12:2

\section{Submit your next manuscript to BioMed Central and take full advantage of:}

- Convenient online submission

- Thorough peer review

- No space constraints or color figure charges

- Immediate publication on acceptance

- Inclusion in PubMed, CAS, Scopus and Google Scholar

- Research which is freely available for redistribution 